\title{
Environmental Airport Design: Towards a New Design and Urban Approach
}

\author{
By Athanasios Athanasopoulos*
}

As nodes for the transportation of goods and people, as well as the modern frontiers of a country, airports do not only play a major economic role in modern society, but also enrich a community's cultural and social cohesion and diversity. As for their impact to the natural and anthropological environment, they represent a very energy-intensive form of transport, which can impose significant changes to the established relationships and hierarchy. Built to host a variety of uses and serve diverse users' groups, large airport terminals evolved from open fields, to shopping centres, to urban hybrids, having an operational magnitude usually equal to that of a modern metropolis, yet of a debatable quality and with no distinct territory or population. Security regulations and market surveys have so far ruled their design, leading to the adoption of a generic development pattern that further isolates them from the surrounding region, regardless of its enhanced accessibility. Therefore, an investigation and analysis of those recent developments and of any limitations and opportunities in regard to an airport's 'urban' scale and characteristics, could prove to be an essential element of the contemporary debate on urban development, economic growth and its impact to the natural and built environment. As an essential first step towards a more sensible approach, this study will try to map this 'territory-less' platform's elements, and serve as a reference base for a future in-depth research on the establishment, development and prospects arising from this new urban environment.

\section{Introduction}

The contemporary debate on airport planning and design aligns with the increasingly troubling concerns regarding urban development, economic growth, and the impact to the natural and built environment. In terms of the city and region's future, under the pressure of dense urbanisation of metropolitan areas and environmental and social sustainability, prosperity cannot be achieved through the exploitation of transportation growth and interconnectivity opportunities alone.

It has been proven that transportation networks and infrastructure are of essential importance to the city's evolution processes. The trend particularly

${ }^{*}$ MPhil in Environmental Design in Architecture Candidate, University of Cambridge, Department of Architecture, Churchill College, UK. 
for airports to expand dramatically in area, intensity and variety of activities can significantly affect them very quickly and in very little time.

In this fragile environment of overlapping or dispersed authority, policy and momentum, 'airport cities' emerge as new trade centres and, by attracting a proportion of the area's population to dwell or work within this new platform, they are transforming into new urban and regional centres. Nevertheless, regardless of their obvious advantages in terms of accessibility to transportation networks, concerns about pollution and environmental and social instability and degradation still lead to scepticism around this urban structure's quality, territory and population.

By discussing about the city's structure as analysed by Mumford, Lynch and a number of other researchers, this essay will attempt to identify essential characteristics, highlight typological patterns, and map this 'territory-less' platform, investigating its urban structure through the comparison of six cases.

In order for the airport city to be recognised as a model of sustainable regional development, its structure must be defined and understood first. Therefore, this study will build the background and support the further development of an in-depth applied field-research on the role and urban characteristics of the airport city as part of a polycentric model for the region's sustainable development.

\section{The City's Structure and its Sustainable Development}

Describing the shift in urban development from the city centre to the periphery, Lewis Mumford (1961) interprets Howard's 'Garden City' as the natural next step in the city's evolution process, once the initial core settlement reaches a maximum size:

'Against the purposeless mass congestion of the big metropolis, [...], a more organic kind of city is opposed. Limited from the beginning in numbers and in density of habitation, limited in area, organised to carry on all the essential functions of an urban community, business, industry, administration, education; equipped too with a sufficient number of public parks and private gardens to guard health and keep the whole environment sweet'.

Further interpreting Mumford's analysis, it can be understood that Howard's main concern was not to create a new community secluded in a pure environment, but a new settlement, the complexity and order of which would support its thriving future, within a spatially and socially interconnected structure of cities.

Other philosophers, architects and planners, like Kropotkin, Gedes, Soria y Mata, Stein, Wright, Fuller, Soleri, Gruen or Le Corbusier, proposed various perspectives and forms of urban development ${ }^{1}$, similarly trying to address the

\footnotetext{
${ }^{1}$ As summarised by Mumford (1961) and Haughton \& Hunter (1994).
} 
task of the ideal city's structure. From an organic to a mechanical system, the city was always perceived as a complex spatial, political and social entity that supports cultural identity and continuity. Moreover, regardless of any morphological variations, they all agreed on the importance of transportation networks in its evolutionary path.

Similarly, Kevin Lynch (1960) interprets the city as 'a multi-purpose, organisation, a tent for many functions, [...], the form of which must be plastic to the purposes and perceptions of its citizens'. Focusing on the city's complex, yet orderly, structure he identifies its essential elements: the path, the edge, the landmark, the nodes, and the regions, and highlights the importance of people being able to understand the space and its characteristics through them. The description of those qualities further strengthens the understanding of the city as a structure of quantitative and qualitative elements, with a delicate hierarchy and a supportive infrastructure, which might at large seem common to all its inhabitants, but remains flexible to various interpretations.

This variety and flexibility in interpreting and designing the city is grasped by Haughton \& Hunter (1994), who understand sustainable urban development as 'a ceaselessly dynamic process, responding to changing economic, environmental and social pressures'. As a result, this process varies among different cases and therefore only general principles can be identified. These principles focus on the natural and built environment's diversity, its resilience against the city's form and operation, the technological interdependencies between them, and the established social coherence, and support Williams' et al. (2000) argument that 'the form of a town/city can affect its sustainability'. Analysing those factors, Orrskog and Snickars (1992) divide them into two types, density and structure, referring to the mass and design quality of the built environment, the expansion and accessibility of infrastructure networks and the intensity of activities and flows.

Analysing further these arguments, several researchers ${ }^{1}$ explore the urbanisation's natural life-cycle stages 'from urbanisation to counterurbanisation, to re-urbanisation', and thus evaluate the transport-oriented qualities of a polycentric development model, compared to a monocentric one. Among this scheme's advantages they recognise the flexibility in addressing congestion and degradation of massive urban cores, the distribution of free spaces within them, transportation demand and urban sprawl, and the characteristics of fringe areas. In the scheme's weaknesses, however, by analysing several case studies in Europe and abroad $^{2}$, one can include the increased vulnerability of the natural environment, and the controversial correlation of a land use mixture ratio or population density with forms of transportation-oriented development, defining the importance of thoroughly understanding each case's particular characteristics in designing a suitable sustainable development plan.

\footnotetext{
${ }^{1}$ Breheny (1992), Orrskog \& Snickars (1992), Hall (2001), Kloosterman \& Lambregts (2001), Dempsey \& Jenks (2005), and Okabe (2005).

${ }^{2}$ Buxton, M. (2000), Newton P. (2000), Simmonds, D., \&Coombe, D. (2000), Kloosterman, R.C., \& Lambregts, B. (2001), and Okabe (2005).
} 


\section{The Role of Transportation Networks in the City's Sustainable Development}

Within this framework, Randall (2003) assesses the transportation networks' essential role in both the city's and region's integral structural balance, and proposes a triangular correlation scheme of their primary characteristics, linking form/density, movement/transport, and buildings/ energy; and recognising, in addition to Clarke (2003) and Thorne \& FilmerSankey (2003), that 'the way in which people and goods move around urban areas determines their structure and function'. This simple, in principle, structure is based on a natural diversity of forms, land uses and travel patterns that ensure its coherence, and establishes its sustainable life-cycle, supporting essential steps regarding the development of the city's characteristics throughout its history ${ }^{1}$.

More recently, it can be argued that Banister (2005) builds on these analyses and on the observed shift in planning policy, to further discuss the role of an integrated transport and land use methodology in supporting growth in a sustainable way. Acknowledging the importance of cities as key points for economic and social development and the scarcity of free land, he highlights transportation networks' significance. Additionally, through various case studies, he revalidates the correlation between a settlement's morphology, travel patterns and energy consumption, proving that a dense urban structure could favour a more sustainable travel pattern, but only up to a certain level; promoting a transport-oriented model for sustainable regional segmentation of urban expansion within a satellite system, similar to Howard's initial motives.

\section{The Role of Airports in the City's Sustainable Development}

\section{Airports as a Transportation Node}

As nodes of major international transportation networks, airports generate a number of flow throughputs and attract various activities to their surrounding areas. Similarly to train stations, airports are described by Güller \& Güller (2003) as cores attracting transportation-oriented development, and 'influencing the growth and shape of the city, especially through the shift of economic activities from its centre to its periphery'. Usually, in a regional scale, the airport, through its main rail or bus station serves as a primary interchange station, but fails to provide adequate public transport accessibility in an extended range within its platform. On the other hand, in a decentralised system of secondary airports, Fasone et al. (2012) describe the promotion of

\footnotetext{
${ }^{1}$ In the case of some provinces in southern Italy, instead of constructing a new large airport, a collective approach is preferred, as it utilises existing infrastructure to satisfy the seasonal increase in aviation traffic. Nevertheless, a long-term evaluation study is still needed to investigate and measure this strategy's actual positive or negative impacts.
} 
lighter and more flexible mobility patterns ${ }^{1}$. As they and other researchers ${ }^{2}$ note however, this development usually happens without a clear planning framework, as the result of a controversial process of forecasting the demand for air-travel and correlating it with economic growth. As a result, the development of these multi-functional nodes has often caused the rearrangement of local transportation networks, with significant consequences to the form and evolution of the surrounding region.

\section{Airport Cities as a New Form of Settlement}

Due to this 'complexity of organisation' accompanying the airport's operation, its area is developing into 'a form comparable to that of a city', a new urban hybrid that emerges among other regional centres; something that Güller \& Güller (2003) are trying to locate within the context of contemporary urbanism by providing the following definition:

'In terms of territorial definition, the airport city is, in principle, the more or less dense cluster of operational, airport-related, activities and other commercial or business concerns, on and around the airport platform. However, this cluster is an airport city only if it shows the qualitative features of a city (density, access quality, environment, services)'.

Moreover, in the US, the term originally meant 'only the business/industrial park near the airport', but it is now often used by Kasarda \& Lindsay (2011) to signify a broader municipality, as in Washington and Denver.

Both these research groups focus on the importance of a structured land use policy about the airport's area, and understand that the growth of an airport city 'is not always inevitable, necessary, or desirable'. They recognise a contemporary planning framework that is based on the airport city as 'the most dynamic motor of urban development', and discuss the possible influences from varying ownership statuses and development perspectives, but identify a limited number of cases where a holistic approach has been established ${ }^{3}$. They do admit that airports 'place excessive and sudden pressures on existing infrastructures, local facilities and the environment ${ }^{4}$ and that they are generally not the appropriate place for intensive housing development, even though, based on their discussion on transport-oriented development theories,

\footnotetext{
${ }^{1}$ OECD (1995), OECD/ECMT (1995), Goodland, R. (2002), and Gilbert, R., \& Nadeau, K. (2002).

${ }^{2}$ Güller \& Güller (2003), Pestana Barros et al. (2009, 2010), Schlaack (2010) and Fasone et al. (2012).

${ }^{3}$ Such as in Stockholm, Helsinki or Zurich, where a regional development strategy is established, incorporating the airport's area as an integral part of the wider urban fabric.

${ }^{4}$ As evidenced by other researchers as well: Banatvala (2004), Morrison (2009), Stettler et al. (2011), Nunes et al. (2011), and Mahashabde et al. (2011).
} 
they indirectly defend the advantages of an airport's workforce residing in close proximity to its platform.

These two definitions, however, have two weaknesses, evident when progressing from the business park to the city level identification. The European approach considers the qualitative features of a city essential, not mentioning, that of a permanent and vivid community, while the American one refers to an actual community, yet to that of the suburban residential enclave, spatially isolated from both the city and the airport; with the reason for that lying probably behind the (un)suitability of the airport's platform as a receptor of residential development, as previously discussed.

Therefore, under the framework of principles established so far to describe the city's structure and evolution paths, it is difficult to identify the 'airport city hybrid' as an emerging prototype of contemporary urbanism, and consolidate its role as one of substituting already established metropolitan centres.

\section{Six Examples - A Case Study}

So far the city's structure and the principles for its transport-oriented sustainable development have been discussed. A more concentrated presentation of the role of transportation infrastructure and particularly airports in this process followed, leading to an investigation of the nature of an 'airport city' as a new form of settlement, within a polycentric scheme. It would be therefore reasonable to further investigate this hypothesis and proceed with an initial analysis of relevant examples.

In this section, six 'airport cities' (Spruce Creek [SUC], Berlin-Tempelhof [THF], Denver [DEN], Frankfurt [FRA], Athens [ATH] and Helsinki [HEL]) will be compared, attempting to identify and map typological patterns, planning characteristics and urban qualities. Even though these examples constitute a small sample, they represent a variety in form and characteristics, and could provide a valuable insight over essential elements of urbanity within the airport's region, often neglected or disregarded. Most of these cases have already been approached in the relevant literature, and their further analysis would provide essential continuity and progress the relevant discussion.

For this process, an investigation based on Kevin Lynch's proposed essential elements of the city (the path, the edge, the landmark, the nodes, and the regions) will be attempted. This is an essential first step in the research on this urban hybrid's optimised integration into the transport-oriented principles towards the city's and region's sustainable evolution. Due to time constraints and the spatial dispersal of these examples around the world however, the present analysis will be based on satellite images, maps, and the information collected from relevant authorities, limiting consequently its breadth. Therefore, every effort was made to secure and present as detailed and accurate information as possible $\mathrm{n}$ the following tables and diagrams. A field-based research in the future, based on exact observations and interviews, could provide an interesting supplement to the initial theoretical conclusions, 
evaluate and re-adjust them, and unveil details and characteristics impossible to investigate under the present approach.

Figure 1. The Six Airport-city Cases (white circle: airport platform, darker circle: city centre, shaded area: airport-city)
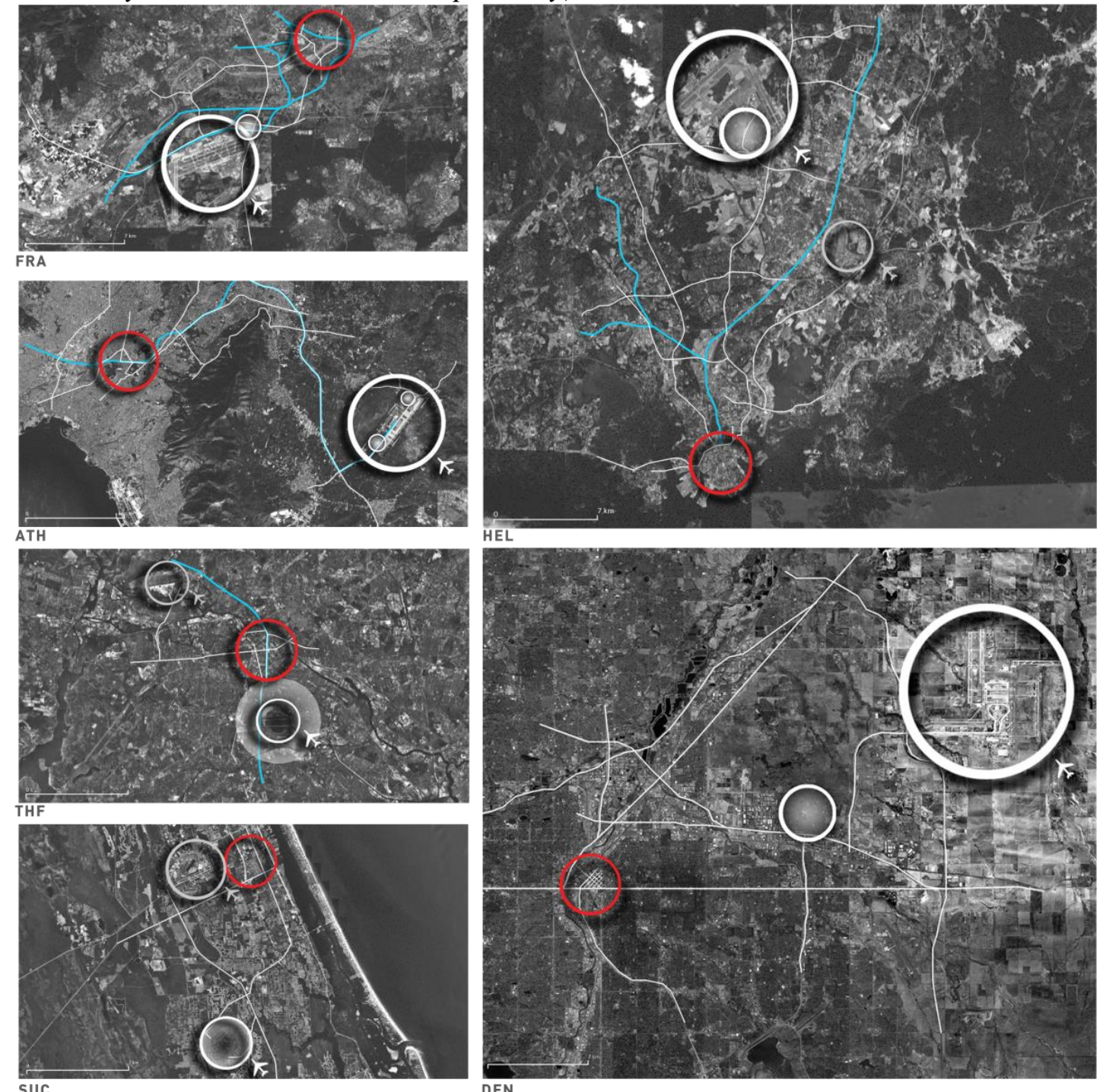
Urban Characteristics

Table 1. Airport-city's Essential Urban Elements

\begin{tabular}{|c|c|c|c|c|c|c|c|}
\hline & & Spruce Creek & Denver & Tempelhof & Frankfurt & Athens & Helsinki \\
\hline Airport City & & $\begin{array}{l}\text { A small community } \\
\text { organised around a } \\
\text { central airport runway }\end{array}$ & $\begin{array}{l}\text { Suburban residential } \\
\text { development far from } \\
\text { the airport / planned } \\
\text { business park }\end{array}$ & $\begin{array}{l}\text { The airport is } \\
\text { built within the } \\
\text { city }\end{array}$ & $\begin{array}{l}\text { Commercial park at } \\
\text { the edge of the } \\
\text { airport's platform }\end{array}$ & $\begin{array}{c}\text { Retail and } \\
\text { conference park, } \\
\text { built within the } \\
\text { airport's platform } \\
\end{array}$ & $\begin{array}{l}\text { Business and retail park at the } \\
\text { fringe area between the city and } \\
\text { the airport }\end{array}$ \\
\hline \multirow{2}{*}{ Path } & Main & Airport runway & Main street & Main street & Highway & Highway & Highway \\
\hline & Secondary & Suburb's streets & Secondary streets & Secondary streets & Secondary streets & Secondary streets & Secondary streets \\
\hline \multirow{2}{*}{ Edge } & Internal & $\begin{array}{l}\text { Between the residences } \\
\text { and the runway }\end{array}$ & $\begin{array}{l}\text { No hard edges apart } \\
\text { from between the main } \\
\text { street and back streets }\end{array}$ & $\begin{array}{l}\text { Between the } \\
\text { main street and } \\
\text { back streets / } \\
\text { dense urban } \\
\text { block }\end{array}$ & $\begin{array}{l}\text { No distinct edges } \\
\text { apart from a light } \\
\text { urban block }\end{array}$ & $\begin{array}{l}\text { Between building } \\
\text { and parking lot }\end{array}$ & $\begin{array}{c}\text { Secondary streets dividing the } \\
\text { area }\end{array}$ \\
\hline & External & Green belt & Outer fence & $\begin{array}{l}\text { Between the } \\
\text { airport building } \\
\text { and the city } \\
\text { buildings / urban } \\
\text { fabric }\end{array}$ & Highway network & $\begin{array}{l}\text { Highway and } \\
\text { airport's fence }\end{array}$ & $\begin{array}{l}\text { Highway, forest and airport's } \\
\text { fence }\end{array}$ \\
\hline Landmark & & $\begin{array}{l}\text { Runway, commercial } \\
\text { area, golf course }\end{array}$ & $\begin{array}{l}\text { School, church, park, } \\
\text { golf course, community } \\
\text { centre, convenient store }\end{array}$ & $\begin{array}{l}\text { Square, subway } \\
\text { station, } \\
\text { esplanade }\end{array}$ & Central roundabout & $\begin{array}{l}\text { Central roundabout, } \\
\text { individual buildings, } \\
\text { chapel, bus stop }\end{array}$ & $\begin{array}{c}\text { Highway exit, forest, individual } \\
\text { buildings, museum }\end{array}$ \\
\hline \multirow[t]{2}{*}{ Nodes } & Main & Airport runway & $\begin{array}{l}\text { Main street - side } \\
\text { streets crossroads }\end{array}$ & $\begin{array}{l}\text { Main street } \\
\text { crossroads and } \\
\text { square } \\
\end{array}$ & Highway exit & Highway exit & Highway interchange and exit \\
\hline & Secondary & $\begin{array}{l}\text { Suburb's streets } \\
\text { crossroads }\end{array}$ & Side streets crossroads & $\begin{array}{l}\text { Side streets } \\
\text { crossroads }\end{array}$ & $\begin{array}{l}\text { Side streets } \\
\text { crossroads }\end{array}$ & $\begin{array}{l}\text { Side streets } \\
\text { crossroads }\end{array}$ & Secondary streets crossroads \\
\hline Regions & & $\begin{array}{l}\text { Clear distinction } \\
\text { between the residential } \\
\text { and commercial / } \\
\text { administrative areas }\end{array}$ & $\begin{array}{l}\text { Large uniform } \\
\text { residential area with } \\
\text { dispersed landmarks }\end{array}$ & $\begin{array}{l}\text { Mixed-use urban } \\
\text { fabric with } \\
\text { higher densities } \\
\text { at local central } \\
\text { points }\end{array}$ & $\begin{array}{l}\text { Small uniform area } \\
\text { with a slightly } \\
\text { different central } \\
\text { point }\end{array}$ & $\begin{array}{l}\text { Two distinct sub- } \\
\text { areas in the opposite } \\
\text { sides of the airport's } \\
\text { platform }\end{array}$ & $\begin{array}{l}\text { Uniform business and residential } \\
\text { areas with retail development in } \\
\text { their periphery }\end{array}$ \\
\hline
\end{tabular}


The different types of airport city development examined present some interesting similarities and differences. All of them show extremely similar path and node patterns and forms, mainly associated with the area's road infrastructure. They also tend to be defined by very sharp or distinct external and penetrable internal edges, which also affect the clarity with which various regions are distinguished. As for the area's landmarks, they interestingly seem to be associated to either the road network, or very distinct buildings and open spaces, the latter only in the cases where significant residential levels can be observed as well.

\section{Area, Accessibility and Land Uses}

Table 2. Airport-city's Particular Characteristics

\begin{tabular}{|c|c|c|c|c|c|c|}
\hline & $\begin{array}{c}\text { Spruce } \\
\text { Creek }\end{array}$ & Denver & Tempelhof & Frankfurt & Athens & Helsinki \\
\hline $\begin{array}{l}\text { Airport's land } \\
\text { ownership }\end{array}$ & Private & Public & Public & Mixed & Public & Public \\
\hline Airport city's land & Private & Private & Mixed & Mixed & Public & Public \\
\hline $\begin{array}{c}\text { Airport's area } \\
\left(\mathrm{mil} . \mathrm{m}^{2}\right)\end{array}$ & 5.2 & 137.3 & 6 & 11.3 & 16.8 & 7.3 \\
\hline $\begin{array}{c}\text { Airport city's area } \\
\left(\mathrm{mil} . \mathrm{m}^{2}\right)\end{array}$ & 5.2 & 10.5 & $-*$ & 0.5 & 0.3 & 2.8 \\
\hline $\begin{array}{l}\text { Airport's distance } \\
\text { from traditional } \\
\text { centre }(\mathrm{km})\end{array}$ & 8 & 37 & 4 & 12 & 20 & 17 \\
\hline $\begin{array}{l}\text { Airport city's distance } \\
\text { from traditional } \\
\text { centre }(\mathrm{km})\end{array}$ & 8 & 20 & 4 & 10 & $18-22$ & 16 \\
\hline $\begin{array}{c}\text { Airport's } \\
\text { accessibility }\end{array}$ & Car & $\begin{array}{l}\text { Car, Local } \\
\text { and regional } \\
\text { bus } \\
\text { (+internal } \\
\text { underground } \\
\text { light rail) }\end{array}$ & $\begin{array}{c}\text { Car, } \\
\text { Subway, } \\
\text { Local bus }\end{array}$ & $\begin{array}{l}\text { Car, Local } \\
\text { and regional } \\
\text { bus, } \\
\text { Suburban, } \\
\text { regional and } \\
\text { national train, } \\
\text { High-speed } \\
\text { rail (+internal } \\
\text { overground } \\
\text { light rail) }\end{array}$ & $\begin{array}{l}\text { Car, Local } \\
\text { and } \\
\text { regional } \\
\text { bus, } \\
\text { Subway } \\
\text { and } \\
\text { suburban } \\
\text { train } \\
\text { (+internal } \\
\text { bus } \\
\text { service) }\end{array}$ & $\begin{array}{l}\text { Car, Local } \\
\text { and regional } \\
\text { buses, +High- } \\
\text { speed rail } \\
\text { (from 2014) }\end{array}$ \\
\hline $\begin{array}{l}\text { Airport city's } \\
\text { accessibility }\end{array}$ & Car & $\begin{array}{l}\text { Car, Local } \\
\text { bus }\end{array}$ & $\begin{array}{c}\text { Car, } \\
\text { Subway, } \\
\text { Local bus }\end{array}$ & $\begin{array}{l}\text { Car, Local } \\
\text { bus }\end{array}$ & $\begin{array}{c}\text { Car, Local } \\
\text { bus } \\
\text { (+internal } \\
\text { busservice) }\end{array}$ & $\begin{array}{l}\text { Car, Local } \\
\text { bus }\end{array}$ \\
\hline $\begin{array}{c}\text { Residential } \\
\text { development }\end{array}$ & $\mathrm{Y}$ & Y & $\mathrm{Y}$ & $\mathrm{N}$ & $\mathrm{N}$ & $\mathrm{Y}$ \\
\hline $\begin{array}{l}\text { Commercial } \\
\text { development }\end{array}$ & $\mathrm{N}$ & $\mathrm{N}^{* *}$ & $\mathrm{Y}$ & $\mathrm{Y}$ & $\mathrm{Y}$ & $\mathrm{Y}$ \\
\hline $\begin{array}{c}\text { Industrial } \\
\text { development }\end{array}$ & $\mathrm{N}$ & $\mathrm{N} * *$ & $\mathrm{Y}^{* * *}$ & $\mathrm{~N}$ & $\mathrm{~N}$ & $\mathrm{Y} * * * *$ \\
\hline Green / public areas & $\mathrm{Y}$ & $\mathrm{Y}$ & $\mathrm{Y}$ & $\mathrm{Y}$ & $\mathrm{N}$ & $\mathrm{Y}$ \\
\hline $\begin{array}{l}\text { Cultural/Community } \\
\text { facilities }\end{array}$ & $\mathrm{Y}$ & Y & $\mathrm{Y}$ & $\mathrm{N}$ & $\mathrm{N}$ & Y \\
\hline
\end{tabular}

*Tempelhof airport is incorporated in Berlin's urban fabric. The airport city's area is not therefore distinct from the city. **Commercial and Industrial uses are developed in nearby locations within other single-use suburban enclaves. $* * *$ In parts of the airport's building, heavy machinery factories were operating until some years prior to the airport's closure. $* * * *$ Light industrial uses are permitted. 
As it appears, a single-use development is often preferred to a mixed-use one, and in almost all cases the airport city is significantly less accessible by public transport than the main airport site. Cultural/Community activities emerge, obviously, only within larger residential areas, while heavy industry is not a preferred use at all, probably due to the high land value. Green areas, in various forms, are unexpectedly common. A relation between the area's size, location and land uses could exist but needs further investigation.

Analysis' Diagrams

Figure 2. Analysis Diagrams (the paths, nodes and edges of the cases examined)
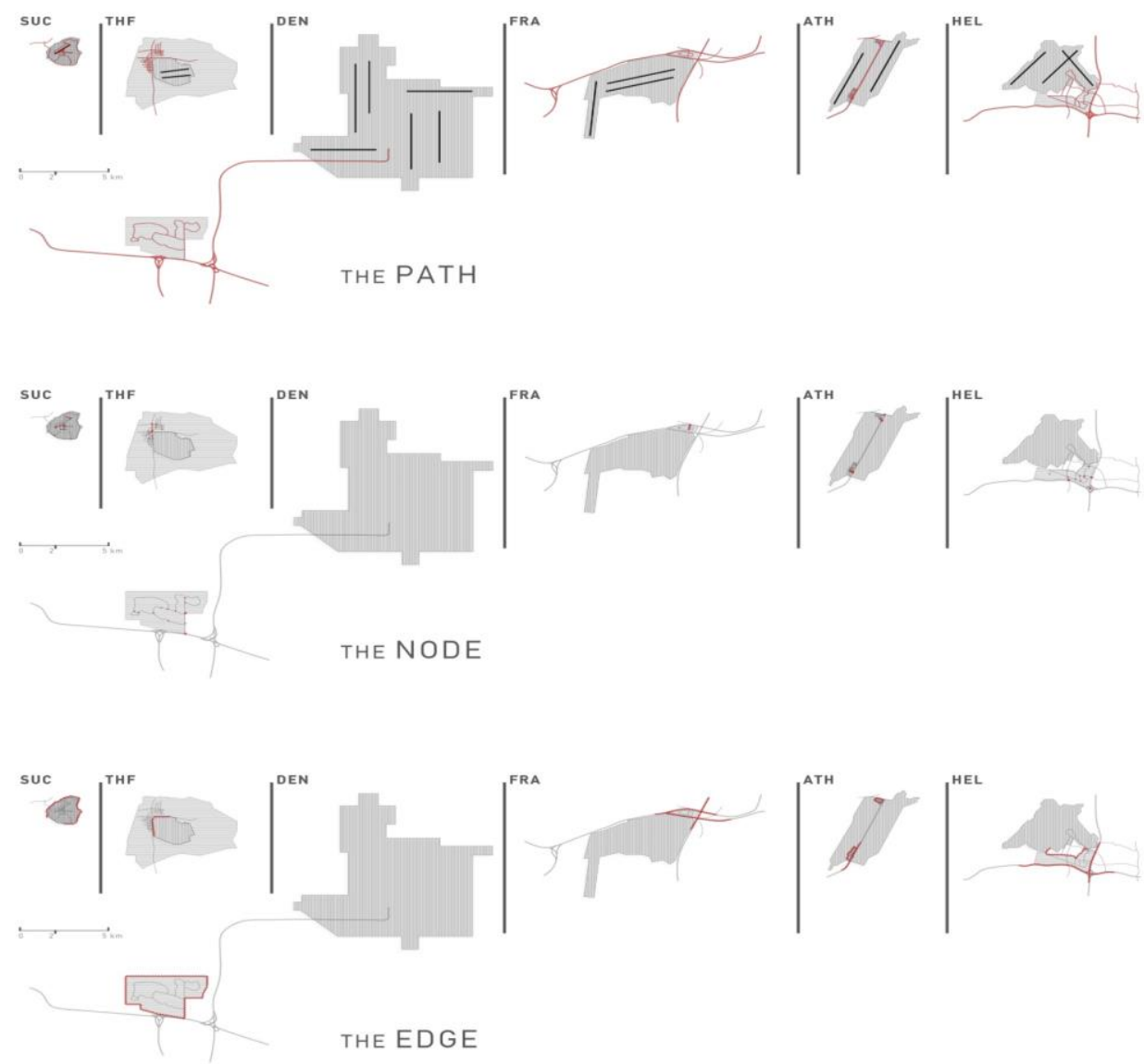

The previous and following figures [sets of diagrams] are trying to map the exact observations described in tables 1 and 2 . In every set of diagrams, a distinct urban element is highlighted, whereas in the last one the total assembly of those characteristics into a single structure is attempted. The initial mapping investigation can demonstrate the various patterns observed, not only as distinct typological features, but as physical data within a certain space, scale, and location as well, to signify the complexity of this new urban hybrid's form. 
Figure 3. Analysis Diagrams [continued] (the landmarks, regions and the complete 'urban' form of the cases examined)
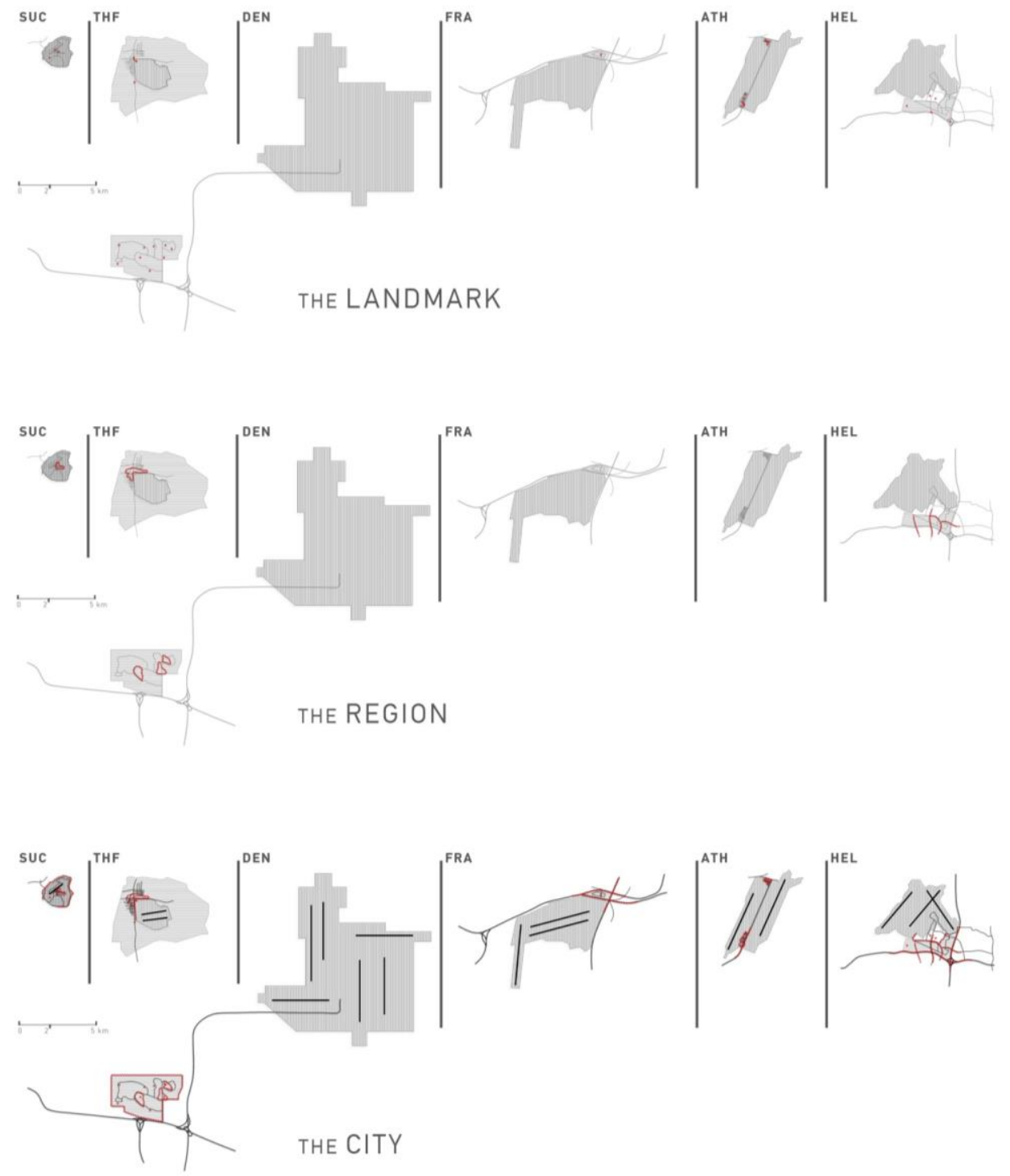

\section{Discussion - Conclusions}

The aim of this essay was to map the 'territory-less city', the contemporary urban hybrid widely known as the 'airport city'. Its purpose was to investigate the existence of any urban qualities within this new urban structure, which would explain the arguments regarding its viability and dominance as a model of sustainable development in a polycentric regional metropolis. Its focus point was on the perceived qualities of this urban environment, as an organic structure of complexity and order, as deriving from the discussion and analysis of the city's structure by Kevin Lynch and other researchers. 
In this process an initial, brief, discussion of their analysis, as well as of the prevailing trends and principles of sustainable urban development, based on models of poly-centricity and transport-oriented development, is held in order to establish the framework of the general discussion.

According to that, it has been proven that such models rely on a distinct mechanism of correlations between form/density, movement/transport, and buildings/energy, shaped by each environment's unique characteristics. As an integral part of this structural triangle, transportation networks have a major role in the city's future. In particular, airports impose tremendous stress to the environment and provide the opportunity for significant economic growth, at the same time. It is therefore understood why, during the last two decades, major airports have evolved from simple buildings to an urban hybrid, causing the rearrangement of networks and their hierarchy within the city's region, far more persistently though and quicker than any other mode of transportation has ever brought about before.

David Banister claims that the vision for the sustainable city would be 'an environmentally attractive, safe city, of high quality, in which people will want to live', yet the present structure of the airport city is still quite distant from this ideal form. The main weakness of the models so far presented by Güller \& Güller, and Kasarda \& Lindsay is the fact that in most cases this new city is a place where no one wants to live, and when it is not, then it retains a form similar to the American suburban enclave, alienating it from both the traditional urban core and the airport itself.

In order to enlighten the case around this controversial territory, an analysis of six examples was attempted. Even though limited in breadth (expandable however through possible future studies), it approaches those new urban forms with relevant detail over their 'urban qualities', and proves that, even though of a diverse morphology, most of them do share certain common features, and that in many cases an airport can coexist sustainably with a community, as an integrated part of its urban fabric and structure.

Amongst all of them, strong similarities can be observed in terms of their paths' characteristics, nodes and hierarchy, as well as of the sharpness of their external edges compared to the penetrability of their internal ones. The latter is probably due to the large uniformity of uses and activities observed, compared to a less common pattern of segmentation. A relation between the area's size, location, land uses and accessibility by public transport, could exist but needs further investigation. The nature, form and dispersal of landmarks within the area seems to depend on all these factors, in addition to other cultural and economic parameters, varying from transportation infrastructure related orientation points, to points of a collective social activity.

It is therefore understood that, even though in some cases certain principles and characteristics of urbanity can be identified, the diversity in this emerging urban hybrid's form and structure is imposing the clearest practical challenges to achieving the right balance between the economic, social and environmental aims that sustainability demands, within both a local and an extended regional framework. 


\section{References}

Banatvala, J. (2004). Unhealthy airports. The Lancet. 21.08.2004 vol.364· pp.: 646 648.

Banister, D. (2005). Unsustainable Transport. City transport in the new century. Routledge. Abingdon' pp.: 2 - 41, 77 - 79, 99 - 128, $211-232,246-255$.

Breheny, M.J. (1992). The contradictions of the compact city: Areview. In: Breheny, M.J. (ed.) Sustainable development and urban form. European Research in Regional Science 2. Pion Ltd. London· pp.: 138 - 159.

Buxton, M. (2000). Energy, Transport and Urban Form in Australia. In: Williams, K., Burton, E., \& Jenks, M. (eds.) Achieving sustainable urban form. E\&FN Spon Press. London \& New York· pp.: $54-63$.

Clarke, P. (2003). Urban planning and design. In: Randall, T. (ed.) Sustainable urban design: An environmental approach. Spon Press. London' pp.: $14-24$.

Dempsey, N., \& Jenks, M. (2005). Future forms of city living. In: Jenks, M., \& Dempsey, N. (eds.) Future forms and designfor sustainable cities. Architectural Press. Oxford \& Burlignton· pp.: $415-417$.

Fasone, V., Giuffre, T., \& Maggiore, P. (2012). Multi-Airport System as a Way of Sustainability for Airport Development: Evidence from an Italian Case Study. Procedia - Social and Behavioral Sciences. Elsevier. vol.53 pp.: 96 - 105.

Gilbert, R., \& Nadeau, K. (2002). Decoupling economic growth and transport demand: A requirement for sustainability. Transportation Research Board. Portland.

Goodland, R. (2002). The Biophysical basis of environmental sustainability. In: van den Bergh, J. (ed.) Handbook of environmental and resource economics. Edward Elgar. Cheltenham· pp.: $709-721$.

Güller, M., \& Güller, M. (2003). From Airport to Airport City. Editorial Gustavo Gili. Barcelona.

Hall, P. (2001). Urban Development and Research Needs in Europe. CERUM Report 8. Umeå University.

Haughton, G., \& Hunter, C. (1994). Sustainable Cities. Sustainable Policy and Development Series 7. Regional Studies Association. Jessica Kingsley Publishers Ltd. London' pp.: $199-311$.

Kasarda, J. D., \& Lindsay, G. (2011). Aerotropolis: The way we'll live next. Allen Lane. London.

Kloosterman, R.C., \& Lambregts, B. (2001). Clustering of economic activities in polycentric urban regions: The case of Randstad. Urban Studies. vol.38, no.4 pp.: $717-732$.

Lynch, K. (1960). The image of the city. MIT Press. Camridge, MA \& London, UK.

Mahashabde, A., et. al. (2011). Assessing the environmental impacts of aircraft noise and emissions. Progress in Aerospace Sciences. Elsevier. vol.47 pp.: 15 - 52.

Morrison, W.G. (2009). Real estate, factory outlets and bricks: A note on nonaeronautical activities at commercial airports. Journal of Air Transport Management. Elsevier. vol.15 pp.: $112-115$.

Mumford, L. (1961). The city in history: Its origins, its transformations, and its prospects. Penguin Books [1991], first published in the UK by Martin Secker \& Warburg Ltd. London' pp.: $549-656$.

Newton P. (2000). Urban form and environmental performance. In: Williams, K., Burton, E., \& Jenks, M. (eds.) Achieving sustainable urban form. E\&FN Spon Press. London \& New York pp.: $46-53$. 
Nunes, L. M., et.al. (2011). Environmental impacts on soil and groundwater at airports: origin, contaminants of concern and environmental risks. Journal of Environmental Monitoring. The Royal Society of Chemistry. vol.13 pp.: 3026 3039.

OECD (1995). Motor vehicle pollution: Reduction strategies beyond 2010. OECD. Paris.

OECD/ECMT (1995). Transport, Energy and Climate Change. Policy Analysis Series. OECD/IEA. Paris· pp.: 133 - 134.

Okabe, A. (2005). Towards the spatial sustainability of city-regions: A comparative study of Tokyo and Randstad. In: Jenks, M., \& Dempsey, N. (eds.) Future forms and designfor sustainable cities. Architectural Press. Oxford \& Burlignton· pp.: 55 -70 .

Orrskog, L., \& Snickars, F. (1992). On the sustainability of urban and regional structures. In: Breheny, M.J. (ed.) Sustainable development and urban form. European Research in Regional Science 2. Pion Ltd. London' pp.: 106 - 121.

Pestana Barros, C., Managi, S., \&, Yoshida, Y. (2010). Productivity growth and biased technological change in Japanese airports. Transport Policy. Elsevier. vol.17 pp.: $259-265$.

--, \& Weber, W. L. (2009). Productivity growth and biased technological change in UK airports. Transport Research Part E. Elsevier. vol.45' pp.: $642-653$.

Randall, T. (ed.) (2003). Sustainable urban design: An environmental approach. Spon Press. London' pp.: 3 - 13.

Schlaack, J. (2010). Defining the Airea: Evaluating urban output and forms of interaction between airport and region. In: Knippenberger, U., \& Wall, A. (eds.) Airports in Cities and Regions - Research and practice. KIT Scientific Publishing. Karlsruhe' pp.: $113-121$.

Simmonds, D., \& Coombe, D. (2000). The transport implications of alternative urban forms. In: Williams, K., Burton, E., \& Jenks, M. (eds.) Achieving sustainable urban form. E\&FN Spon Press. London \& New York pp.: $121-130$.

Stettler, M.E.J., Eastham, S., \& Barrett, S.R.H. (2011). Air quality and public health impacts of UK airports. Part 1: Emissions. Atmospheric Environment. Elsevier. vol.45 pp.: $5415-5424$.

Thorne, R, \& Filmer-Sankey, W. (2003). Transportation. In: Randall, T. (ed.) Sustainable urban design: An environmental approach. Spon Press. London pp.: $25-32$.

Williams, K., Burton, E., \& Jenks, M. (eds.) (2000). Achieving sustainable urban form. E\&FN Spon Press. London \& New York pp.: $1-7$.

- Detailed information about the six airport-city cases: http://www.aia.gr/ : Athens airport's official webpage. http://www.berlin-airport.de/ : Berlin airports' official webpage. http://www.flydenver.com/ : Denver airport's official webpage. http://www.flughafentempelhof.com/ : History and information for Berlin's Tempelhof airport.

http://www.fraport.com : Frankfurt airport's official webpage. http://www.helsinki-vantaa.fi : Helsinki airport's official webpage.

http://www.scpoa.com/airport/ : Spruce Creek property owners association's webpage.

(Date of last access to the web-pages: 08.04.2013)

- All maps and diagrams presented in this essay are designed and drawn by the author, based on the information available in the relevant literature and the analysis conducted. 